Dhaka Univ. J. Biol. Sci. 31(1): 45-67, 2022 (January) DOI: https://doi.org/10.3329/dujbs.v31i1.57915

\title{
FLORISTIC COMPOSITION OF PLANKTON IN SHITALAKHSYA RIVER, NARAYANGANJ, DHAKA
}

\author{
Mohammad Azmal Hossain Bhuiyan*, Md Rasikul Islam, SAM Shariar Islam ${ }^{1}$, \\ Abu Kowser AND MoniruzZaman KHONDKER \\ Department of Botany, University of Dhaka, Dhaka-1000, Bangladesh
}

Key words: Phytoplankton flora, River Shitalakhsya, Chlorophyta, Bacillariophyta, Euglenophyta

\begin{abstract}
Information of phytoplankton flora of polluted river ecosystems of Bangladesh are scanty. The present study was undertaken to explore the phytoplankton flora at Dakshin Rupshi Station of the river Shitalakhsya, Narayanganj, Dhaka. The study was carried out from May 2017 to March 2018 by collecting pelagic plankton samples bimonthly. A total of 53 species under 36 genera were identified, of which 51 species have been illustrated through photomicrographic images and listing. Two species of phytoplankton namely, Pyrobotrys incurva Arnoldi and Phacus ranula Pochmann were identified from the river water but could not be produced here. The recorded algal divisions of phytoplankton are Cyanophyta (6), Chlorophyta (19), Euglenophyta (13), Chrysophyta (13) and Pyrrhophyta (2). The standing crops presented by each division are: $463.5,428.33,199.67,664.33$ and $26.25 \times 10^{3}$ ind $/$ by Cyanophyta, Chlorophyta, Euglenophyta, Chrysophyta and Pyrrhophyta, respectively. The trend in contributing the number of species is Chlorophyta > Euglenophyta and Chrysophyta > Cyanophyta > Pyrrhophyta. For standing crop, the trend is Chrysophyta > Cyanophyta $>$ Chlorophyta $>$ Euglenophyta $>$ Pyrrhophyta. Pollutant loading from the urban sources actually cuts the penetration of light into the upper part of the river water and thus creating a shrinking environment for the survival of phytoplankton. The present floristic study of phytoplankton of the River Shitalakhsya adds knowledge to the species composition and their systematic position which would be helpful for any further floristic study of phytoplankton on the river ecosystems of Bangladesh.
\end{abstract}

\section{Introduction}

In river ecosystems, species composition i.e., quality and quantity of phytoplankton determines the flora in free moving water. Though their hydraulic residence time in a flowing river is very short and unstable, they keep on synthesising carbohydrate in presence of sunlight utilising free $\mathrm{CO}_{2}$ sources present in water. This process is vital for the pelagic grazing food chain as well as to serve as an indicator to the trophic state of

\footnotetext{
*Author for correspondence: <bhuiyan.azmal@gmail.com>. 1Plant Biotechnology and Genetic Engineering Division, Institute of Food and Radiation Biology (IFRB), AERE, Bangladesh Atomic Energy Commission, Savar, Dhaka-1349, Bangladesh.
} 
any river(1). The phytoplankton of river is also termed as potamoplankton ${ }^{(2)}$ and in Limnology though a number of studies related to quantitative aspects of this specialized community has been worked out there exists a little information in its floristic composition. Whitton ${ }^{(1)}$ and Reynolds ${ }^{(2)}$ highlighted some generic occurrences of potamoplankton in some rivers but truly floristic composition of river phytoplankton has still been neglected.

Bangladesh is the country of rivers having a total length of $24,140 \mathrm{~km}^{(3)}$. Phytoplankton of rivers do play a great role in operating grazing food chain. But which kinds of phytoplankton do dominate our river ecosystem is mostly unanswered? Islam and Haroon ${ }^{(4)}$ and Islam and Zaman ${ }^{(5)}$ carried out the floristic work on the phytoplankton of the river Buriganga near Dhaka in mid-seventies. The river was little polluted then and the recorded number of coccoid, unicellular, colonial and filamentous cyanobacteria, diatoms, desmids and chlorococcoid algae from the planktonic flora of the river were rich. Not much significant research work had been carried out on the floristic composition of running water plankton in Bangladesh. Apart from this, Islam and Aziz ${ }^{(6)}$ had carried out another floristic study on the Karnaphuli river estuary and recorded the occurrences of cyanobacterial flora, diatom, euglenoid, and chlorococcoid forms of plankton. Recently, some research works on potamoplankton biomass, primary productivity, and periodicity in relation to water quality of some peripheral rivers of Dhaka Metropolis had been carried out ${ }^{(7-11)}$. But still, the information on the floristic composition of phytoplankton in the water of the river Shitalakhsya, Narayanganj are scanty. The present study has therefore been undertaken to study the floristic composition of phytoplankton from a section of the river Shitalakhsya, Narayanganj.

\section{Materials and Methods}

Samples of phytoplankton from Dakhshin Rupshi Station of the river Shitalakhsya was collected bimonthly from May 2017 to March 2018. The collection was made following the sedimentation technique by using Lugol's iodine. Details of the sample collection procedure together with the morphometric features of the study side and seasonality of water quality data have been presented in Bhuiyan et al. ${ }^{(11)}$. After obtaining the phytoplankton concentrate via sedimentation, compound microscopy was carried out with the help of a microplankton counting chamber (Helber Microplankton Counting Chamber, Thoma Ruling, Hawksley Technology, UK) and a phase contrast compound microscope (Zeiss, Axio, Lab. A1, Germany) attached with photographic attachment (Zeiss Axiocam ERc 5s, Germany). Multicolored images of each phytoplankton species were shot at magnifications ranging from 200-400x. During microscopy, diameter of colony (col.), length and breadth of trichome (trich.), filament (fil.) and frustules (fr.), cell diameter (dia.) and length (l.) all were measured and recorded. With the help of all this data, each plankton individual was identified up to the species and/or higher taxonomic 
ranks by consulting various monographs, publications, and books on phytoplankton taxonomy ${ }^{(12-17)}$. Helps from the national compendium, Encyclopedia of Flora and Fauna of Bangladesh were also taken for the identification of taxa(18-26). For the systematic arrangements of the collected species, the hierarchy presented by Bold and Wynne ${ }^{(27)}$ was followed.

All the images of phytoplankton flora as recorded via microscopy from the samples collected from the study station of the river Shitalakhsya were presented in Figs. 1-51. Their list with some diagnostic features and the literatures used for the identification of each taxon has been tabulated in Table 1 .

\section{Results and Discussion}

During the period of the investigation, a total of 24 phytoplankton samples were collected from the Shitalakhsya River. The recorded phytoplankton genera were 36 belonging to 5 algal Divisions. The total number of species recorded was 53, their division wise distribution is: Cyanophyta (6), Chlorophyta (19), Euglenophyta (13), Chrysophyta (13), and Dinophyta (2). The standing crops presented by each division are: 463.5, 428.33, 199.67, 664.33, and $26.25 \times 10^{3}$ ind $/$ by Cyanophyta, Chlorophyta, Euglenophyta, Chrysophyta, and Pyrrhophyta, respectively. A detail account of the population dynamics of the planktonic flora together with their relationships with water quality data have been presented in Bhuiyan et al.(11). Table 1 showed the list of 51 species of phytoplankton along with their morphometric features and literature sources of their identification. An illustrative account of the species has been provided in Figs. 1-51. Two species though recorded and identified from the river water but could not be produced here. Those species are: Pyrobotrys incurva Arnoldi and Phacus ranula Pochmann.

From the river Shitalakhsya, a record of 51 species in the community of phytoplankton is low. Islam and Zaman ${ }^{(5)}$ obtained 194 species of phytoplankton from the river Buriganga near Dhaka Metropolis. Bhuiyan and Khondker(9) reported 30 species of phytoplankton from the River Buriganga and 22 species from the River Gomti of Cumilla. Urban sections of most of the rivers of Bangladesh have been getting heavy load with organic and metal pollutions over time. This has a severe consequence on floristic composition of phytoplankton of rivers. When the data of Islam and Zaman(5) and Bhuiyan and Khondker ${ }^{(9)}$ on the Buriganga river are compared, a reduction of $84 \%$ in the species composition of planktonic flora has been observed over a period of 43 years span. Both the river Shitalakhysya and the river Buriganga are flowing through the heavily industrialized areas of Dhaka Metropolis and Narayanganj city and as a result have been exposed to strong pollution conditions. The phytoplankton species recorded for the Shitalakhsya and the Buriganga river are 51 and 30, respectively in the recent time (present study and Bhjuiyan and Khondker)(9). If 3-key water quality parameters are considered as the governing elements such as Secchi depth (Zs), Soluble reactive 
Table 1. Species list of phytoplankton from the River Shitalakhsya along with their diagnostic features and literature sources of identification.

\begin{tabular}{|c|c|c|c|}
\hline Figs. & Species & Dimensions $(\mu \mathrm{m})$ & References \\
\hline 1 & Aphanocapsa littoralis Hansg. & col. dia. 276.8 & Desikachary(27), p. 100, fig. 1 \\
\hline 2 & Merismopedia glauca (Ehrenb.) Naeg. & col. $15.0 \times 10.0$ & Desikachary $^{(27)}$, p.151, fig. 5 \\
\hline 3 & Oscillatoria formosa Bory & trich. $301.5 \times 12.5$ & Prescott( 17$),$ p. 878 , fig. 10 \\
\hline 4 & Oscillatoria subbrevis Schmidle & trich. $125.2 \times 15.0$ & Desikachary(27), p. 204, fig. 2 \\
\hline $5 a-c$ & $\begin{array}{l}\text { Arthrospira platensis var. non-constricta } \\
\text { (Banerji) comb. nov. }\end{array}$ & $\begin{array}{l}\text { trich. } 67.5-182.5 \times \\
10.0-17.0\end{array}$ & Desikachary(27), p.194, fig. 1-2. \\
\hline $6 a-b$ & Anabaena fertilissima Rao & fil. $197.5 \times 15.0$ & Desikachary ${ }^{(27)}$, p. 402 , fig. 3 \\
\hline 7 & Pandorina morum (Müller) Bory & col. dia. 95 & $\begin{array}{l}\text { Islam }^{(18)} \text {, p. 696; Prescott(17), pl.1, fig. } \\
63\end{array}$ \\
\hline $8 a-d$ & Eudorina elegans Ehrenberg & $\begin{array}{l}\text { col. dia. } 135 \\
\text { cell dia. } 12.5\end{array}$ & $\begin{array}{l}\text { Ling \& Tyler(12), p. 123, pl. 55, figs. 5, } \\
\text { 6; Islam }{ }^{(18)} \text {, p.695 }\end{array}$ \\
\hline $9 a, b$ & $\begin{array}{l}\text { (a) Volvox carteri Stein (showing daughter } \\
\text { colony inside mother colony), (b) V. carteri } \\
\text { (daughter colonies released) }\end{array}$ & col. dia. 120 & Islam and Zaman ${ }^{(5)}$, p. 48 , pl. 1 , fig. 2 \\
\hline 10 & Radiococcus wildmanii (Schmidle) Schmidle & $\begin{array}{l}\text { col. } 102.5 \times 122.5 \\
\text { cell } 12.5\end{array}$ & Begum(19), p.117 \\
\hline 11 & Oocystis pusilla Hansgirg & col. dia. 70 cell 17.5 & Ling \& Tyler(12), p. 101, pl. 45 , fig. 4 \\
\hline 12 & Diacanthos belenophorus Koršikov & & 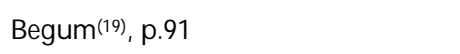 \\
\hline 13 & Ankistrodesmus falcatus (Corda) Ralfs & cell $80 \times 5$ & Begum ${ }^{(19)}$, p.588 \\
\hline 14 & $\begin{array}{l}\text { Monoraphidium mirabile (W. \& G.S. West) } \\
\text { Pankow }\end{array}$ & cell $95 \times 5$ & $\begin{array}{l}\text { Ling \& Tyler(12), p. 105, pl. 42, figs. } \\
16,17\end{array}$ \\
\hline 15 & Secenedesmus acuminatus (Lager.) Chodat & col. $140.0 \times 77.5$ & Ling \& Tyler(12), p. 423, fig. 11 \\
\hline 16 & S. denticulatus Lagerheim & $\begin{array}{l}\text { col. } 42.5 \times 32.5 \\
\text { cell } 12.5\end{array}$ & Ling \& Tyler(12), p. 111 , pl. 52, fig. 10 \\
\hline 17 & S. quadricauda (Turp.) de Breb. & $\begin{array}{l}\text { col. } 140 \times 77.5 \\
\text { chaete } 47.5 \text { long }\end{array}$ & Begum ${ }^{(19)}$, p.641 \\
\hline 18 & P. duplex Meyen & col. dia. $57.5 \times 92.5$ & $\begin{array}{l}\text { Ling \& Tyler(12), p. 92, pl. } 41 \text {, figs. } \\
\text { 1,4; } \operatorname{Prescott}^{(17)}, \text { pl.48, fig. } 4\end{array}$ \\
\hline 19 & $\begin{array}{l}\text { Pediastrum duplex var. gracillimum West \& } \\
\text { West }\end{array}$ & $\begin{array}{l}\text { col. dia. } 100-125 \\
100\end{array}$ & Ling \& Tyler(12), p. 93, pl. 40, fig. 6 \\
\hline 20 & P. duplex var. reticulatum Lagerheim & 100 & Begum $^{(19)}$, p.515 \\
\hline 21 & $\begin{array}{l}\text { Pleurotaenium trabecula (Ehr.) Naeg. var. } \\
\text { trabecula }\end{array}$ & cell $215 \times 10$ & $\begin{array}{l}\text { Islam and } \operatorname{Zaman}^{(5)} \text {, p. 51, pl. 4, fig. } \\
48\end{array}$ \\
\hline 22 & Cosmarium pardalis Chon. & $\begin{array}{l}\text { cell } 62.5-77.5 \times 30.0- \\
57.5\end{array}$ & Begum \& Khondker(21), p.256 \\
\hline 23 & C. paulii Islam \& Haroon & cell $87.5 \times 60.0$ & Begum \& Khondker(21), p.257 \\
\hline 24 & $\begin{array}{l}\text { Staurastrum saltans Joshua var. sumatranum } \\
\text { Scott and Prescott }\end{array}$ & cell $75 \times 90$ & Nasima(25), p. 466 \\
\hline 25 & Cyclotella comensis Grunow in Van Heureck & $\begin{array}{l}\text { dia. } 12.5-17.5 \text { striae } \\
7.2 / 10 \text { micron }\end{array}$ & Khondker \& Bhuiyan(24), p. 192. \\
\hline
\end{tabular}




\begin{tabular}{|c|c|c|c|}
\hline Figs. & Species & Dimensions $(\mu \mathrm{m})$ & References \\
\hline 26 & Coscinodiscus excentricus Ehr. & dia. 80 & Begum $^{(20)}$, p. $61-62$ \\
\hline \multirow[t]{2}{*}{27} & Melosira granulata (Ehrenberg) Ralfs & chain $255 \times 25$ & Hustedt(16), p. 87 , fig. 44 \\
\hline & & cell $22.4 \times 25.0$ & \\
\hline 28 & Melosira granulata var. angustisima Müller & $\begin{array}{l}\text { chain } 162.5-375.0 \times 10.0- \\
37.5\end{array}$ & Hustedt ${ }^{(16)}$, p. 88 , fig. 45 \\
\hline 29 & Fragilaria virescens Ralfs & chain $240 \times 10$ & $\operatorname{Germain}^{(14)}$, p. 68 , pl. 22, fig. 1 \\
\hline \multicolumn{4}{|l|}{$32 \mathrm{~d}$} \\
\hline 30 & Fragilaria construens (Ehrenberg) Grun. & chain $122.5 \times 20.0$ & Hustedt(16), p. 141, fig. 135 \\
\hline 31 & Fragilaria intermedia (Grunow) Grunow & chain $92.5 \times 27.5$ & Begum $^{(20)}$, p.103 \\
\hline $\begin{array}{l}32 a-c, \\
e-i\end{array}$ & Synedra ulna (Nitz.) Ehrenberg & $\begin{array}{l}\text { fr. } 72.5-132.5 \times 7.5-20 \\
\text { striae } 7.2 / 10 \text { micron }\end{array}$ & 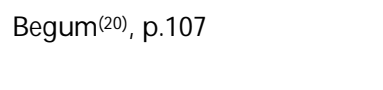 \\
\hline 33 & Rhopalodia gibba (Ehrenberg) O. Müll. & fr. $112.5 \times 22.5$ & Hustedt(16), 390, fig. 739 \\
\hline 34 & Gomphonema longiceps var. subclavata Grun. & fr. $82.65 \times 16.53$ & Hustedt $^{(16)}$, p. 375 , fig. 705 \\
\hline 35 & $\begin{array}{l}\text { Gomphonema lanceolatum Ehrenberg var. } \\
\text { insignis (Gregory) Cleve }\end{array}$ & fr. $82.5-122.5 \times 15.0-17.5$ & Hustedt(16), p. 374, fig. 701 \\
\hline 36 & Nitzschia filiformis (W. Stein) Hust. & fr. $71 \times 5$ & Hustedt ${ }^{(16)}$, p. 422 , fig. $818 \mathrm{c}$ \\
\hline 37 & $\begin{array}{l}\text { Surirella robusta Ehrenberg var. splendida } \\
\text { (Ehrenberg) van Heureck }\end{array}$ & fr. $162.5 \times 62.5$ & Hustedt(16), p. 437-438, fig. 852 \\
\hline 38 & $\begin{array}{l}\text { Ceratium furca (Ehrenberg) Claprède } \text { et } \\
\text { Lachman }\end{array}$ & cell $217.5-305 \times 35-62.5$ & Aziz ${ }^{(26)}$, p. 406 \\
\hline 39 & Peridinium gutwinski Wolos. & cell $72.5 \times 52.5$ & $\begin{array}{l}\text { Ling \& Tyler(12), p. } 67, \text { pl. } 25 \text {, } \\
\text { fig. } 12\end{array}$ \\
\hline 40 & Euglena acus Ehrenberg & cell $177.5-187.5 \times 15.0$ & $H-P^{(15)}, 16$, fig. $75 c$ \\
\hline 41 & Euglena charkowiensis Swirenko & cell $172.5 \times 45.0$ & H-P(15), pl. 6, fig. 37d \\
\hline 42 & Euglena ehrenbergii Klebs & cell $150-170 \times 47.5-65.0$ & H-P(15), pl. 9, fig.15 \\
\hline 43 & Euglena oblonga Schmitz & cell $70 \times 30$ & Khondker(22), p. 248 \\
\hline 44 & Euglena spathirhyncha Skuja & $\begin{array}{l}\text { cell } 157.5- \\
182.5 \times 12.530 .0\end{array}$ & Khondker(22), p. 256 \\
\hline 46 & Euglena splendens Dang & cell $45 \times 35$ & Khondker(22), p. 258 \\
\hline 46 & Lepocinclis salina Fritsch & cell 55.0- 57.5×40.0-42.5 & Khondker(22), p. 270 \\
\hline 47 & $\begin{array}{l}\text { Phacus acuminatus var. granulata (Roll) } \\
\text { Huber-Pest. }\end{array}$ & cell $55 \times 40$ & Khondker(22), p. 275 \\
\hline 48 & Phacus circumflexus Poch. & cell $97.5 .5 \times 52.5$ & H-P(15), fig. 307a, Pl. L \\
\hline 49 & Phacus concavus Hortobagyi & cell $135.0 \times 52.5$ & Khondker(22), p. 281 \\
\hline 50 & Phacus longicauda (E.) Duj. & cell $170 \times 62.5$ & H-P(15), fig. 299a, pl. XLIX \\
\hline 51 & $\begin{array}{l}\text { Trachelomonas hispida var. coronata Lemm. fa. } \\
\text { irregularis Khondker }\end{array}$ & lorica $59 \times 40$ & Khondker et al. (23) \\
\hline
\end{tabular}



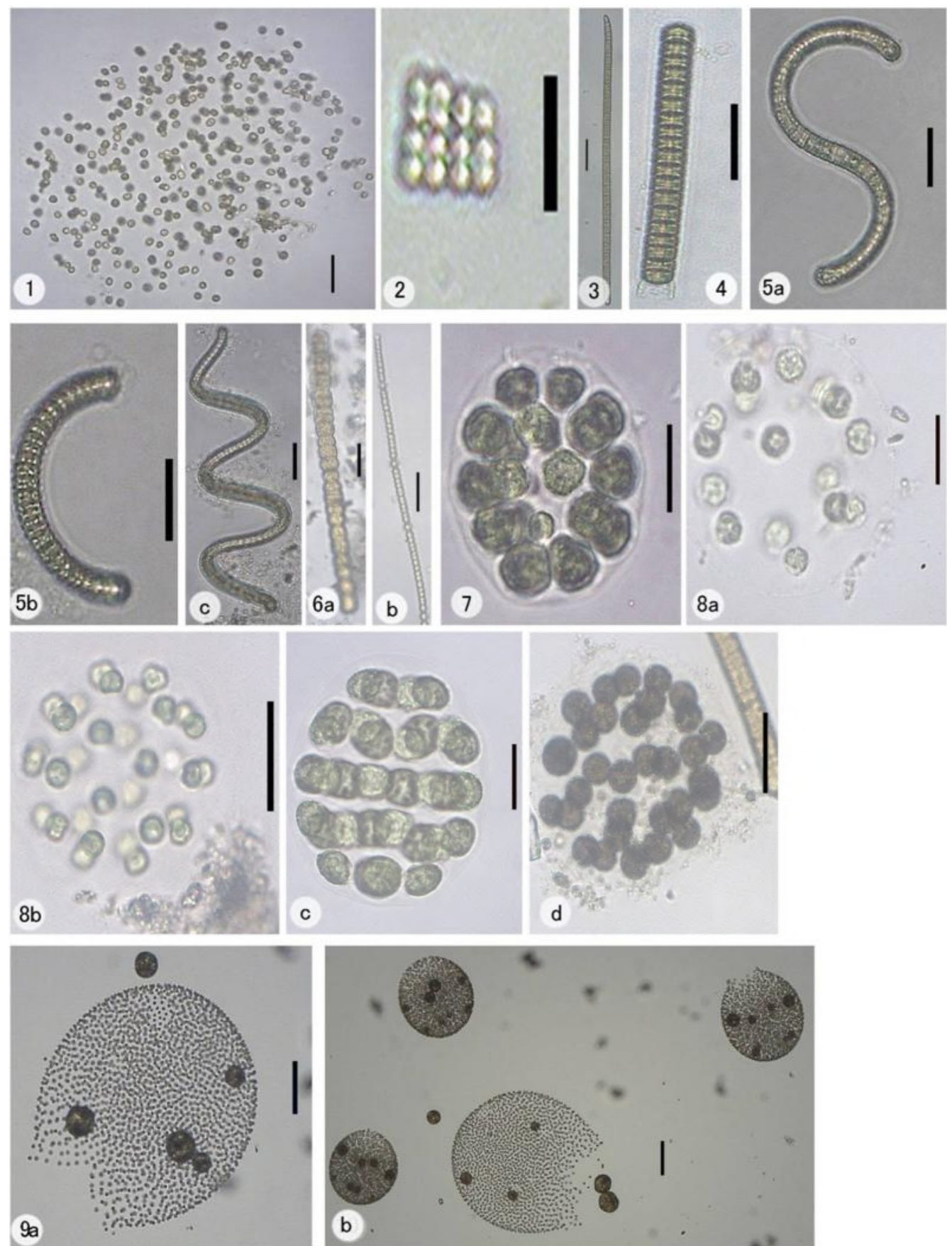

Figs 1-9. 1. Aphanocapsa littoralis. 2. Merismopedia glauca. 3. Oscillatoria formosa. 4. O. subbrevis. 5a-c. Arthrospira platensis var. non-constricta. 6a-b. Anabaena fertilissima. 7. Pandorina morum. 8a-d. Eudorina elegans. 9a-b. Volvox carteri. (Scales $=25 \mu \mathrm{m})$. 

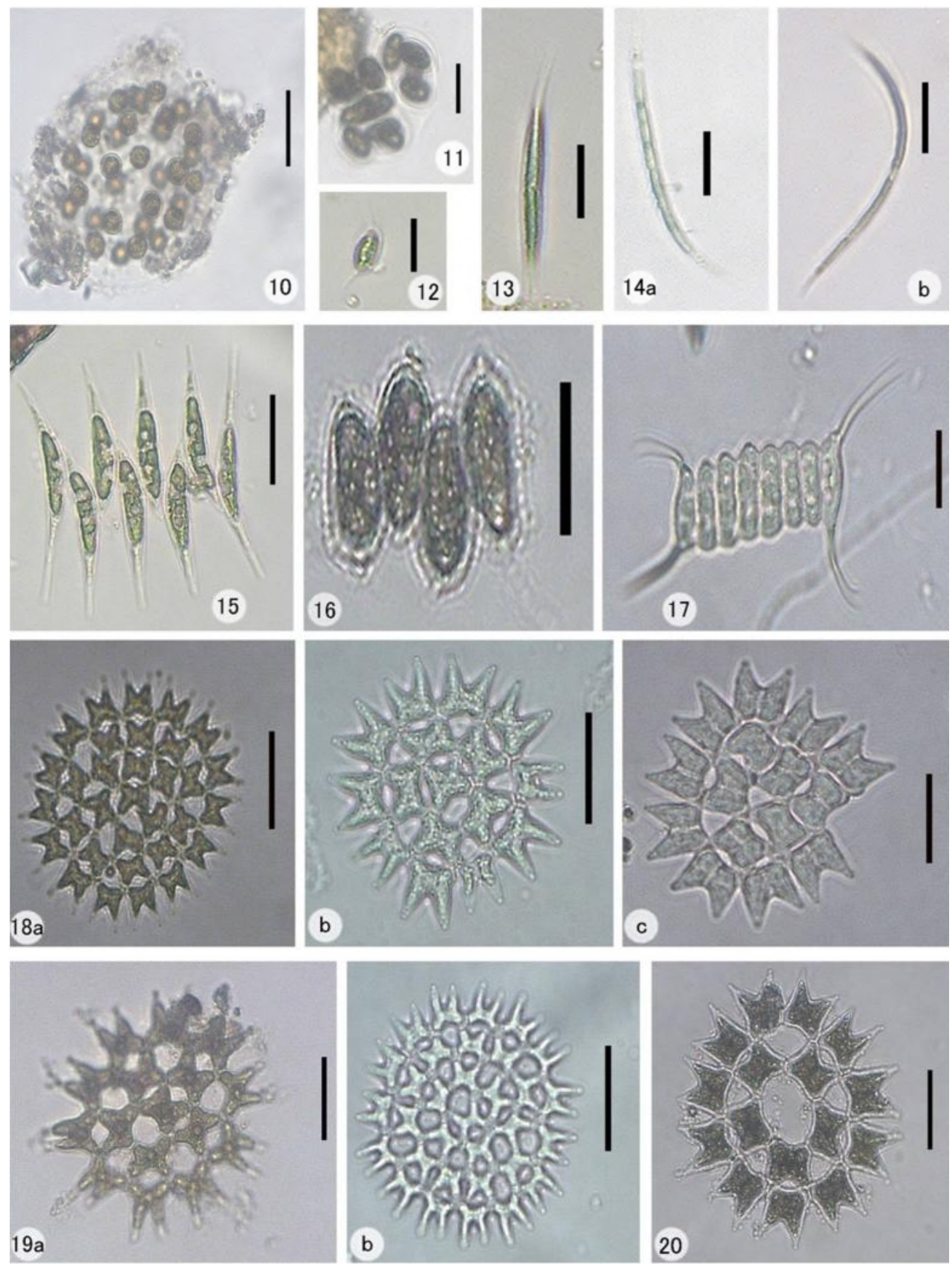

Figs 10-20. 10. Radiococcus wildmanii. 11. Oocystis pusilla. 12. Diacanthos belenophorus. 13. Ankistrodesmus falcatus. 14. Monoraphidium mirabile. 15. Scenedesmus acuminatus. 16. S. denticulatus. 17. S. quadricauda. 18a-c. Pediastrum duplex. 19a-b. P. duplex var. gracillimum. 20. P. duplex var. reticulatum. (Scales $=25 \mu \mathrm{m})$. 

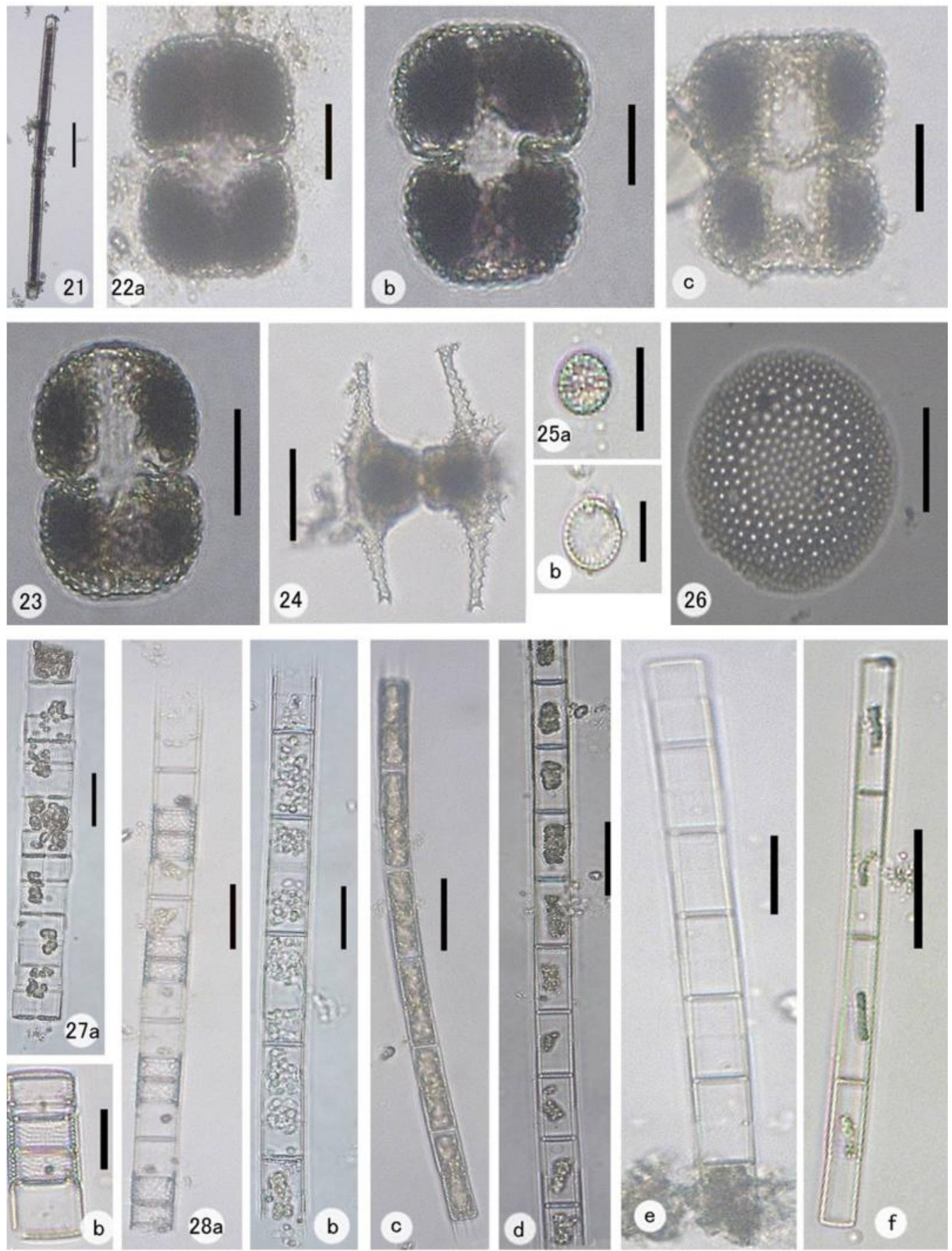

Figs 21-28. 21. Pleurotaenium trabecula. 22a-c. Cosmarium pardalis. 23. C. paulii. 24. Staurastrum saltans var. sumatranum. 25a-b. Cyclotella comensis. 26. Coscinodiscus excentricus. 27a-b. Melosira granulata. 28a-f. M. granulata var. angustisima. (Scales $=25 \mu \mathrm{m}$ ). 

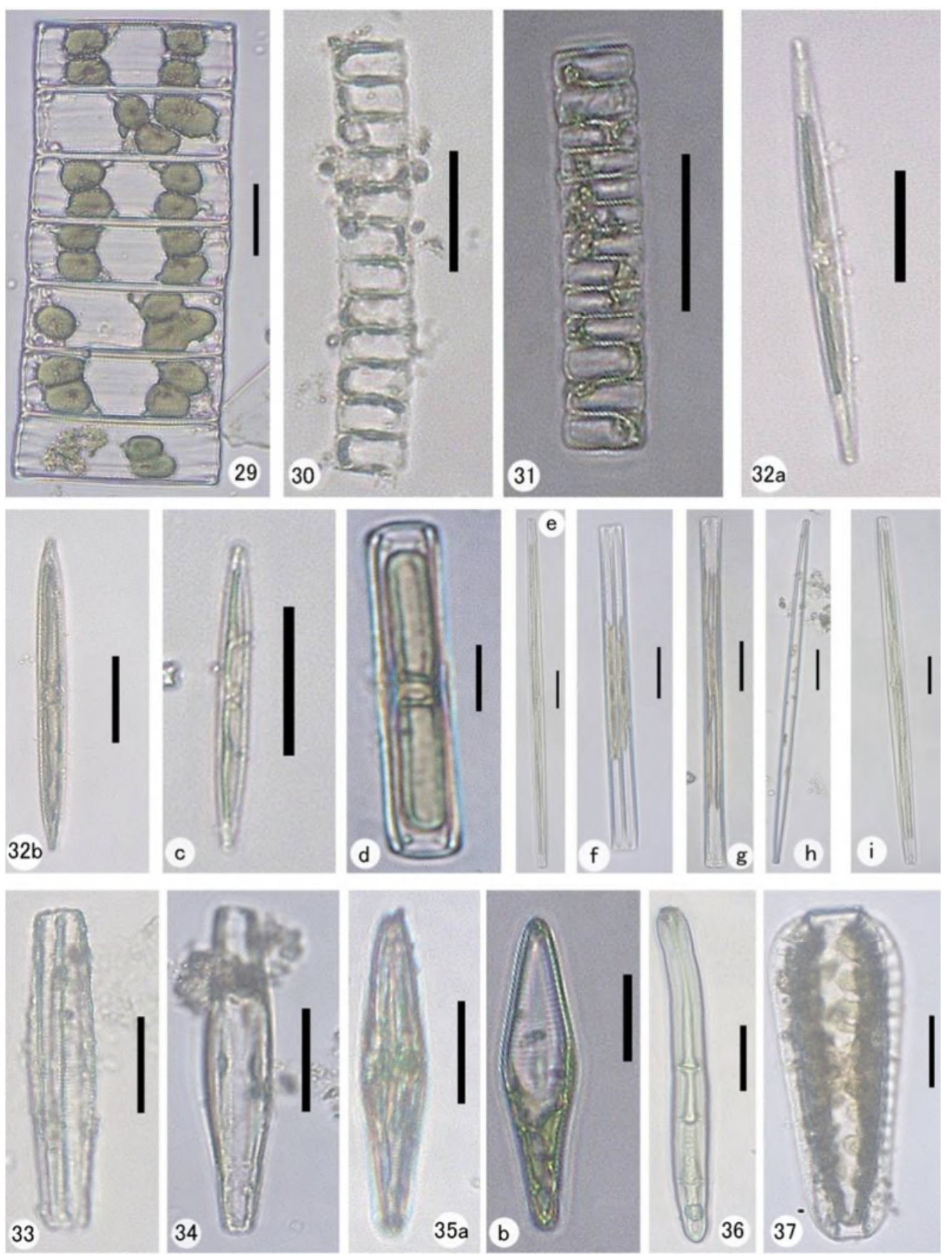

Figs 29-37. 29. 32d. Fragilaria virescens. 30. F. construens. 31. F. intermedia. 32a-c. e-i. Synedra ulna. 33. Rhopalodia gibba. 34. Gomphonema longiceps var. subclavata. 35a-b. Gomphonema lanceolatum var. insignis. 36. Nitzschia filiformis. 37. Surirella robusta. (Scales $=25 \mu \mathrm{m})$. 

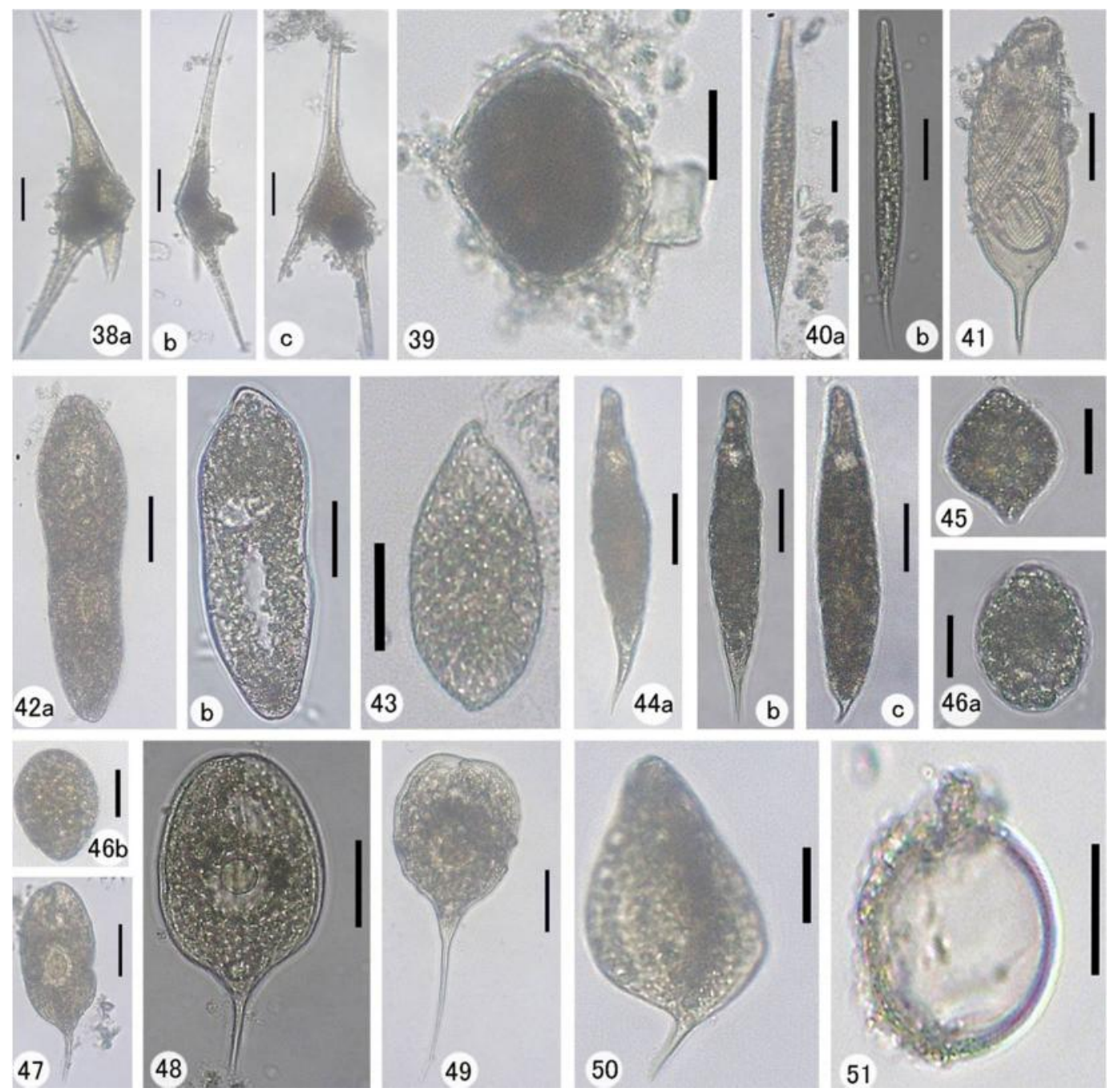

Figs 38-51. 38a-c. Ceratium furca. 39. Peridinium gutwinski. 40a-b. Euglena acus. 41. E. charkowiensis. 42a-b. E. ehrenbergii. 43. E. oblonga. 44a-c. E. spathyrhyncha. 45. E. splendens. 46a-b. Lepocinclis salina. 47. Phacus acuminatus var. granulata. 48. P. circumflexus. 49. P. concavus. 50. P. longicauda. 51. Trachelomonas hispida var. coronata fa. irregularis. (Scales $=25 \mu \mathrm{m}$ ).

phosphorus (SRP) and $\mathrm{NO}_{3}-\mathrm{N}^{(9,11)}$ then a big similarity can be observed in both the river Shitalakhsya and the river Buriganga (Zs, $0.48 \mathrm{~m}$; SRP, $327 \mu \mathrm{g} \Lambda$; $\mathrm{NO}_{3}-\mathrm{N}, 550 \mu \mathrm{g}$; ; and Zs, $0.54 \mathrm{~m}$; SRP, $493 \mu \mathrm{g} \Lambda$ and $\mathrm{NO}_{3}-\mathrm{N}, 810 \mu \mathrm{g} \Lambda$, respectively for the Shitalakhsya and the Buriganga). It clearly indicates that heavy organic load in the river water drastically cuts the light penetration (as observable with low Zs data). On the other hand, concentration of the key nutrients SRP and $\mathrm{NO}_{3}-\mathrm{N}$ increases. In aquatic ecosystems, qualitative aspects of inhabiting species i.e., the number of species respond inversely to the nutrient 
conditions. It means higher the concentration of nutrients lower the number of species. So, there is a strong scientific basis for the record of relatively lower number of phytoplankton species in the river Shitalakhsya.

Considering the floristic composition of phytoplankton, as worked out in the present research, some species were found common in occurrences ${ }^{(5,8,9)}$. For example, Volvox carteri, Eudorina elegans, Pandorina morum, Arthrospira platensis, Aphanocapsa littoralis, Pediastrum duplex, Scenedesmus acuminatus, Ankistrodesmus falcatus, Melosira granulata, Cyclotella comensis, Fragilaria intermedia, Synedra ulna, Euglena acus, etc. are most common in occurrences. However, in some European river, species of Stephanodiscus, Cyclotella, Melosira, Asterionella, Navicula, Chlamydomonas, Gonium, Chlorella, Pediastrum, Scenedesmus, Ankistrodesmus, etc. are common ${ }^{(1-2)}$.

In the present study it has been revealed that urban sections of some rivers in greater Dhaka area are supported by relatively low number of species of phytoplankton. And that the pollutant load, light limitation, increased concentrations of nitrogen and phosphorus can be responsible for the lower diversity of phytoplankton. Researches on qualitative study of river water inhabiting true plankton are rare in Bangladesh and we find the results of the present study as an addition to fill up the existing knowledge gaps. Species of phytoplankton from the river Shitalakhsya are listed along with their illustrative account with the help of photomicrography. So, it might become helpful to the limnologists for further evaluation of any floristic study of planktonic population of river ecosystems of Bangladesh.

\section{References}

1. Whitton BA 1975. Algae. In: Whitton BA (Ed.). River Ecology. Algae. Blackwell Scientific Publ. Oxford, London, UK. 81-105 pp.

2. Reynolds CS 1988. In: Round FE (Ed.). Algae of the Aquatic Environment. Potamoplankton: Paradigms, paradoxes and prognoses. Biopress Ltd. Bristol, UK. 384 pp.

3. Islam N (Ed.) 2017. National Atlas of Bangladesh. Aisat. Soc. Bangladesh, Dhaka. 442 pp.

4. Islam AKMN and AKY Haroon 1975. Limnological studies of the river Buriganga. II. Biological aspect. Dacca Univ. Stud. B 21(1): 25-44.

5. Islam AKMN and KM Zaman 1975. Limnological studies of the river Buriganga. III. Biological aspect. J. Asiatic Soc. Bangladesh (Sci.) 1(1): 45-65.

6. Islam AKMN and A Aziz 1977. Studies on the phytoplankton of the Karnaphuli river estuary. J. Bangladesh Acad. Sci. 1(2): 141-154.

7. Khondker M and G Abed 2013. Seasonality of phytoplankton productivity of the river Turag of Dhaka in relation to its water quality. Bangladesh J. Bot. 42(2): 287-294.

8. Zerin L, A Gani and M Khondker 2017. Comparative water quality assessment of the river Buriganga near Dhaka metropolis. Bangladesh J. Bot. 46(2): 589-598.

9. Bhuiyan $\mathrm{MAH}$ and $\mathrm{M}$ Khondker 2018. Water quality and potamoplankton of the river Buriganga and Gomti: A comparison. Dhaka Univ. J. Biol. Sci. 27(2): 191-200. 
10. Bhuiyan MAH, SAMS Islam, A Kowser, MR Islam, SA Kakoly, K Asaduzzaman and M Khondker 2019. Effects of water quality on phytoplankton biomass in Balu River, Dhaka, Bangladesh. J. Biod. Cons. Biores. Manag. 6(1): 37-46.

11. Bhuiyan MAH, MR Islam, SAMS Islam, A Kowser, SA Kakoly, M Mohid and M Khondker 2021. Water quality and potamoplankton periodicity of Shitalakhshya river, Narayanganj, Dhaka. Dhaka Univ. J. Biol. Sci. 30 (2 Centennial Special Issue): accepted.

12. Ling HU and PA Tyler 2000. Australian Freshwater Algae (exclusive of diatoms). Bibl. Phycol. Bd. 105.J. Cramer, Berlin. 643 pp.

13. Desikachary TV 1959. Cyanophyta. Indian Council of Agric. Research. New Delhi. 686 pp.

14. Germain H 1981. Flore des diatomees Diatomophycees. Societe Nouvelle des Editions Boubee, Paris. 444 pp.

15. Huber-Pestalozzi G 1968. Das Phytoplankton des Sü̈swassers. Systematik und Biologie. 3. Teil: Cryptophyceae, Chloromonadophyceae, Dinophyceae. E. Schweizerbart'sche Verlagsbuchhandlung (Nägele u. Obermiller), Stuttgart, Germany. 322 pp.

16. Hustedt F 1930. Die Suesswasserflora Mitteleuropas. Heft. 10, Bacillariophyta (Diatomeae). Verlag Gustav Fisher, Jena. 466 pp.

17. Prescott GW 1982 (Reprint). Algae of the Western Great Lakes Area. Otto Koeltz Sci. Publ., Koeningstein, W-Germany. pp. 977.

18. Islam AKMN 2008. Pandorina morum (Müller) Bory.; Eudorina elegans Ehrenberg. In: Ahmed ZU, ZNT Begum, MA Hassan, M Khondker, SMH Kabir, M Ahmad, ATA Ahmed, AKA Rahman and EU Haque (Eds.). Encyclopedia of Flora and Fauna of Bangladesh. Vol. 3, Algae, Chlorophyta (Aphanochaetaceae-Zygnemataceae). Asiatic Society of Bangladesh, Dhaka. p. 695.696.

19. Begum ZNT 2008. Radiococcus wildmanii (Schmidle) Schmidle; Diacanthos belenophorus Koršikov; Ankistrodesmus falcatus (Corda) Ralfs; Scenedesmus quadricauda (Turp.) de Breb; Pediastrum duplex var. reticulatum Lagerheim. In: Ahmed ZU, ZNT Begum, MA Hassan, M Khondker, SMH Kabir, M Ahmad, ATA Ahmed, AKA Rahman and EU Haque (Eds.). Encyclopedia of Flora and Fauna of Bangladesh. Vol. 3, Algae, Chlorophyta (AphanochaetaceaeZygnemataceae). Asiatic Society of Bangladesh, Dhaka. p. 91,117, 515, 588, 641.

20. ZNT Begum 2009. Coscinodiscus excentricus Ehrenberg; Fragilaria intermedia (Grunow) Grunow; Synedra ulna (Nitz.) Ehrenberg. In: Ahmed ZU, M Khondker, ZNT Begum, MA Hassan, SMH Kabir, M Ahmad, ATA Ahmed and AKA Rahman (Eds.). Encyclopedia of Flora and Fauna of Bangladesh. Vol. 4, Algae, Charophyta-Rhodophyta (Achnanthaceae-Vaucheriaceae). Asiatic Society of Bangladesh, Dhaka. p. 61-62, 103, 107.

21. Begum ZNT and M Khondker 2008. Cosmarium pardalis Chon.; Cosmarium paulii Islam \& Haroon. In: Ahmed ZU, ZNT Begum, MA Hassan, M Khondker, SMH Kabir, M Ahmad, ATA Ahmed, AKA Rahman and EU Haque (Eds.). Encyclopedia of Flora and Fauna of Bangladesh. Vol. 3, Algae, Chlorophyta (Aphanochaetaceae-Zygnemataceae). Asiatic Society of Bangladesh, Dhaka. p. 256, 257. 
22. Khondker M 2009. Euglena oblonga Schmitz; Euglena spathyrhyncha Skuja; Euglena splaendens Dang, Lepocinclis salina Fritsch, Phacus acuminatus var. granulata (Roll) Huber-Pest., Phacus concavus Hortobagy. In: Ahmed ZU, M Khondker, ZNT Begum, MA Hassan, SMH Kabir, M Ahmad, ATA Ahmed and AKA Rahman (Eds.). Encyclopedia of Flora and Fauna of Bangladesh. Vol. 4, Algae, Charophyta-Rhodophyta (Achnanthaceae-Vaucheriaceae). Asiatic Society of Bangladesh, Dhaka. p. 248, 256, 258, 270, 275, 281.

23. Khondker M, RA Bhuiyan, J Yeasmin, M Alam, RB Sack, A Huq and RR Colwell 2008. New records of phytoplankton for Bangladesh. 8. Trachelomonas Ehrenberg (Euglenophyceae). Bangladesh J. Bot. 37(2): 133-139.

24. Khondker M and RA Bhuiyan 2009. Cyclotella comensis Grunow in Van Heureck. In: Ahmed ZU, M Khondker, ZNT Begum, MA Hassan, SMH Kabir, M Ahmad, ATA Ahmed and AKA Rahman (Eds.). Encyclopedia of Flora and Fauna of Bangladesh. Vol. 4, Algae, Charophyta-Rhodophyta (Achnanthaceae-Vaucheriaceae). Asiatic Society of Bangladesh, Dhaka. p. 192.

25. Nasima A 2008. Staurastrum saltans Joshua var. sumatranum Scott and Prescott. In: Ahmed ZU, ZNT Begum, MA Hassan, M Khondker, SMH Kabir, M Ahmad, ATA Ahmed, AKA Rahman and EU Haque (Eds.). Encyclopedia of Flora and Fauna of Bangladesh. Vol. 3, Algae, Chlorophyta (Aphanochaetaceae-Zygnemataceae). Asiatic Society of Bangladesh, Dhaka. p. 466.

26. Aziz A 2009. Ceratium furca (Ehrenberg) Calprè et Lachman. In: Ahmed ZU, M Khondker, ZNT Begum, MA Hassan, SMH Kabir, M Ahmad, ATA Ahmed and AKA Rahman (Eds.). Encyclopedia of Flora and Fauna of Bangladesh. Vol. 4, Algae, Charophyta-Rhodophyta (Achnanthaceae-Vaucheriaceae). Asiatic Society of Bangladesh, Dhaka. p. 406.

27. Bold HC and MJ Wynne 1985. Introduction to the Algae. $2^{\text {nd }}$ edn. Prentice Hall Inc., London. pp. 720. 